\title{
PENERAPANGMP DI UNIT PERKEBUNAN KAKAO PTPN XII KENDENG LEMBU BANYUWANGI
}

\author{
Putri Istianingrum ${ }^{1)}$, Yusmia Widiastuti ${ }^{2}$, Khairul Barriyah, ${ }^{3)}$ \\ *) Program Studi Agroteknologi, Fakultas Pertanian dan Perikanan, Universitas17 Agustus 1945 Banyuwangi \\ Jl.Adi. Sucipto, Taman Baru, Kec. Banyuwangi, Kabupaten Banyuwangi, Jawa Timur 68416.
}

putriistianingrum@untag-banyuwangi.ac.id. yusnia@untag-banyuwangi.ac.id.khoirulbariyyah@untag-banyuwangi.ac.id

\begin{abstract}
ABSTRAK
Kakao merupakan salah satu komoditas andalan perkebunan yang peranannya cukup penting bagi perekonomian nasional.Untuk kesuksesan jangka panjang, perlu memperhatikan tiga hal pokok yang sangat mempengaruhi tingkat keberhasilan produk di pasaran, yaitu harga, ketersediaan, dan mutu.. Untuk mewujudkan sistem mutu dan keamanan pangan, salah satunya adalah dengan Good Manufacturing Practices (GMP) atau Cara Produksi Pangan yang Baik. Penelitian ini bertujuan untuk mengetahui trend produksi kakao yang dihasilkan selama tahun 2006 - 2016 , penerapan GMP dan GMP prioritas di PTPN XII Kendeng Lembu. Penelitian ini menggunakan metode deskriptif dengan analisa kuantitatif. Untuk pengambilan data dilakukan dengan metode survey dan observasi ditunjang dengan data sekunder yang didapat dari instansi terkait. Analisa yang dilakukan adalah dengan Trend dan Forecasting, Penentuan level pelaksanaan GMP, dan Analysis Hierarchy Process. Berdasarkan analisa yang dilakukan, trend kakao edel dirumuskan sebagai $Y=255,028-20,750 X$, sementara trend kakao bulk dirumuskan $Y=-94,910+47,357 X$. Tingkat pelaksanaan GMP di PTPN XII Kendeng Lembu Banyuwangi secara keseluruhan adalah sebesar 65,95\% yang artinya adalah tingkat penerapan komponen dan sub komponen GMP di PTPN XII Kendeng Lembu tergolong agak tinggi. Untuk AHP ada 36,51\% sub komponen yang berada dalam kondisi yang kurang optimal sehingga harus ditingkatkan dan diperbaiki
\end{abstract}

\section{Kata kunci : Trend, Good Manufacturing Practice, Kakao}

\section{PENDAHULUAN}

Pengembangan agroindustri seringkali lepas dari perhatian, padahal sebagai bagian dari agribisnis, agroindustri memiliki peranan penting dalam kemajuan perekonomian Indonesia. Ada 5 (lima) alasan agroindustri penting untuk menjadi lokomotif pertumbuhan ekonomi nasional masa depan, yaitu (a) industri pengolahan mampu mentransformasikan keunggulan komparatif menjadi keunggulan kompetitif, produknya memiliki nilai tambah dan pangsa pasar yang besar sehingga kemajuan yang dicapai dapat mempengaruhi pertumbuhan ekonomi nasional secara keseluruhan, (c) memiliki keterkaitan yang besar baik ke hulu maupun ke hilir, (d) memiliki basis bahan baku lokal sehingga terjamin sustainabilitasnya, (e) berpeluang mentransformasikan struktur ekonomi nasional dari pertanian ke industri dengan agroindustri sebagai motor penggeraknya (Supriyati dkk, 2006).

Salah satu produk pertanian di sektor perkebunan yang berperan dalam pengembangan agroindustri adalah kakao. Kakao merupakan salah satu komoditas andalan perkebunan yang peranannya cukup penting bagi perekonomian nasional, khususnya sebagai penyedia lapangan kerja, sumber pendapatan dan devisa negara. Perkebunan kakao di Indonesia mengalami perkembangan pesat dalam kurun waktu 20 tahun terakhir dan pada tahun 2015 areal perkebunan kakao Indonesia tercatat seluas 1,72 ha. Perkebunan kakao tersebut sebagian 
besar $(88,48 \%)$ dikelola oleh rakyat dan selebihnya $5,59 \%$ perkebunan besar swasta (Direktorat Jenderal Perkebunan, 2016)

Dari segi kualitas, kakao Indonesia tidak kalah dengan kakao dunia dimana bila dilakukan fermentasi dengan baik dapat mencapai cita rasa setara dengan kakao yang berasal dari Ghana dan kakao Indonesia mempunyai kelebihan yaitu tidak mudah meleleh sehingga cocok bila dipakai untuk blending. Sejalan dengan keunggulan tersebut, peluang pasar kakao Indonesia cukup terbuka baik ekspor maupun kebutuhan dalam negeri. Dengan kata lain, potensi untuk menggunakan industri kakao sebagai salah satu pendorong pertumbuhan dan distribusi pendapatan cukup terbuka. Hal ini dapat dilihat pada tabel 1 yang menunjukkan kebutuhan kakao di Indonesia untuk kebutuhan ekspor yang cukup menjanjikan.

Tabel 1 Volume Nilai Ekspor - Impor Kakao di Indonesia Periode Tahun 2011 - 2015

\begin{tabular}{lcc}
\hline & Tahun & \multicolumn{2}{c}{ Ekspor } \\
\cline { 2 - 3 } & Volume (Ton) & Nilai ( 00 US\$) \\
\hline $\mathbf{2 0 1 1}$ & 410.257 & 1.345 .429 \\
$\mathbf{2 0 1 2}$ & 387.790 & 1.053 .533 \\
$\mathbf{2 0 1 3}$ & 414.092 & 1.151 .494 \\
$\mathbf{2 0 1 4}$ & 333.679 & 1.244 .530 \\
$\mathbf{2 0 1 5}$ & 350.730 & 1.316 .867 \\
\hline
\end{tabular}

\section{Sumber : Direktorat Jenderal Perkebunan}

Jika ditinjau dari produksinya selama kurun waktu 1980-2016 (Angka Estimasi), produksi kakao Indonesia juga berfluktuasi dan cenderung meningkat. Pada tahun 1980 produksi kakao Indonesia sebesar 10.284 ton. kemudian tahun 2015 sebesar 661.243 ton atau mengalami peningkatan rata-rata sebesar $13,99 \%$ per tahun. Dari hasil estimasi Ditjen Perkebunan, produksi kakao tahun 2016 akan naik $15,00 \%$ dibandingkan tahun 2015. Produksi tertinggi selama periode tahun 1980-2016 terjadi pada tahun 2010 yaitu sebesar 837.918 ton. Pada periode tahun 2012-2016 atau selama lima tahun terakhir, rata-rata pertumbuhan produksi kakao naik sebesar 1,63\% per tahun.. Hal ini bisa dilihat pada Gambar 1.

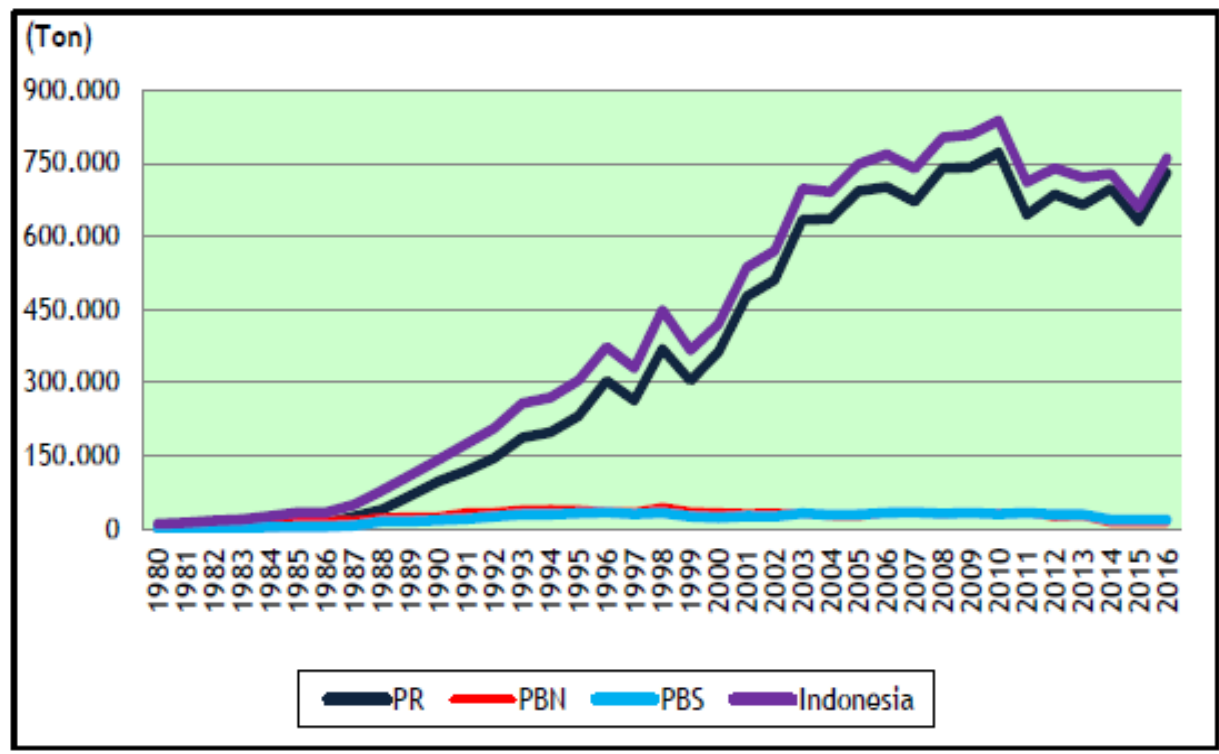

Gambar 1. Perkembangan Produksi Kakao di Indonesia Menurut Status Pengusahaan, Tahun 1980-2016 (Sumber : Pusat Data dan Sistem Informasi Pertanian, Sekretariat Jenderal Kementerian Pertanian) 
PTPN XII Kendeng Lembu adalah salah satu perkebunan yang menjadikan kakao sebagai sentra produksinya. Hal ini bisa dilihat dari luas lahan yang disediakan untuk budidaya kakao (tabel 2).

\begin{tabular}{|c|c|c|}
\hline No & $\begin{array}{c}\text { Jenis } \\
\text { Tanaman }\end{array}$ & Luas Lahan \\
\hline 1 & Karet & $503,47 \mathrm{Ha}$ \\
\hline 2 & Kakao E & 890,90 Нa \\
\hline 3 & Kakao B & $954,16 \mathrm{Ha}$ \\
\hline 4 & Kayuan & $256,04 \mathrm{Ha}$ \\
\hline
\end{tabular}

\section{Sumber : PTPN XII Kendeng Lembu}

Dari tabel 2, dapat dilihat bahwa pembudidayaan kakao memiliki potensi dengan luasnya lahan yang digunakan. Namun tidak hanya luas lahan kakao yang menjadi perhatian. Untuk kesuksesan jangka panjang, perlu memperhatikan tiga hal pokok yang sangat mempengaruhi tingkat keberhasilan produk di pasaran, yaitu harga, ketersediaan, dan mutu. Untuk mewujudkan sistem mutu dan keamanan pangan, salah satunya adalah dengan Good Manufacturing Practices (GMP) atau Cara Produksi Pangan yang Baik.

Keamanan pangan adalah sebuah konsep yang digunakan untuk menjamin dan mencegah penyakit atau bahan yang berbahaya agar tidak turut dikonsumsi oleh manusia (Anonim, 2008). Perdagangan global memberikan dampak terhadap produk pertanian, baik produk hewani maupun tanaman pangan, yaitu munculnya jasa keamanan pangan. Beberapa isu tentang keamanan pangan produk pertanian yang meresahkan masyarakat adalah kasus antraks, keracunan susu, avian influence (flu burung), cemaran mikroba patogen pada produk ternak, dan cemaran aflatoksin pada jagung dan kacang tanah (Wuryaningsih, 2007).

Apabila keamanan pangan suatu produk rendah dan tidak ada upaya pencegahan dari produsen sebagai penyedia produk dan ketelitian konsumen sebagai pengguna produk, maka keamanan produk yang rendah berpotensi menimbulkan foodbornedisease bagi konsumen. Foodborne disease adalah penyakit yang disebabkan karena mengkonsumsi bahan pangan yang terkontaminasi mikroorganisme patogen (Anonim, 2008).

Cara Produksi Makanan yang Baik (CPMB) atau Good Manufacturing Practices (GMP) adalah suatu pedoman cara berproduksi makanan yang bertujuan agar produsen memenuhi persyaratan-persyaratan yang telah ditentukan untuk menghasilkan produk makanan bermutu dan sesuai dengan tuntutan konsumen, Dengan menerapkan CPMB diharapkan produsen pangan dapat menghasilkan produk makanan yang bermutu, aman dikonsumsi dan sesuai dengan tuntutan konsumen, bukan hanya konsumen local tetapi juga konsumen global. Sauer dalam Velasquez (2007) menyatakan bahwa Good Manufacturing Practices (GMP) adalah pondasi untuk program keamanan pangan yang lain. Good Manufacturing Practices (GMP) merupakan prosedur dan program yang digunakan pada fasilitas pangan untuk memastikan keamanan produksi pangan. Good Manufacturing Practices (GMP) meliputi prosedur untuk sanitasi, keamanan, keamanan pangan, dan pemeliharaan fasilitas untuk menghasilkan produk bermutu yang aman dikonsumsi, termasuk juga keselamatan pekerja di dalamnya.

Untuk mewujudkan sistem mutu dan keamanan pangan, salah satunya adalah dengan Good Manufacturing Practices (GMP) atau Cara Produksi Pangan yang Baik. Penerapan GMP merupakan kebutuhan dalam rangka meningkatkan mutu dan keamanan produk, mengingat kakao yang diproduksi 
oleh unit perkebunan PTPN XII Kendeng Lembu sudah menembus pasar ekspor. Namun realitanya di PTPN XII Kendeng lembu belum diketahui tingkat penerapan GMP menurut ketentuan yang diteliti.

Berdasarkan hal tersebut, maka perlu dilakukan penelitian mengenai Good Manufacturing Practices (GMP) di Unit Perkebunan PTPN XII Kendeng Lembu, sehingga diharapkan PTPN XII Kendeng Lembu akan dapat mempertahankan dan meningkatkan mutu produk secara ekonomis, dan pada akhirnya juga akan memperkuat posisi tawar produk kakao PTPN XII Kendeng Lembu di pasar lokal maupun di pasar global

Tujuan penelitian adalah untuk mengetahui trend produksi kakao yang dihasilkan PTPN XII Kendeng Lembu selama tahun 2006 - 2016, penerapan GMP di PTPN XII Kendeng Lembu, dan GMP prioritas di PTPN XII Kendeng Lembu

\section{METODE PENELITIAN}

Penelitian dilakukan di di Unit Perkebunan Kakao PTPTN XII Kendeng Lembu Kecamatan Glenmore Kabupaten Banyuwangi. Unit Perkebunan Kakao PTPTN XII Kendeng Lembu merupakan perusahaan perkebunan swasta berfokus pada bidang perkebunan, perdagangan, dan industri kakao. Tahapan penelitian dapat dijelaskan dalam bentuk diagram seperti yang terlihat pada Gambar 2.

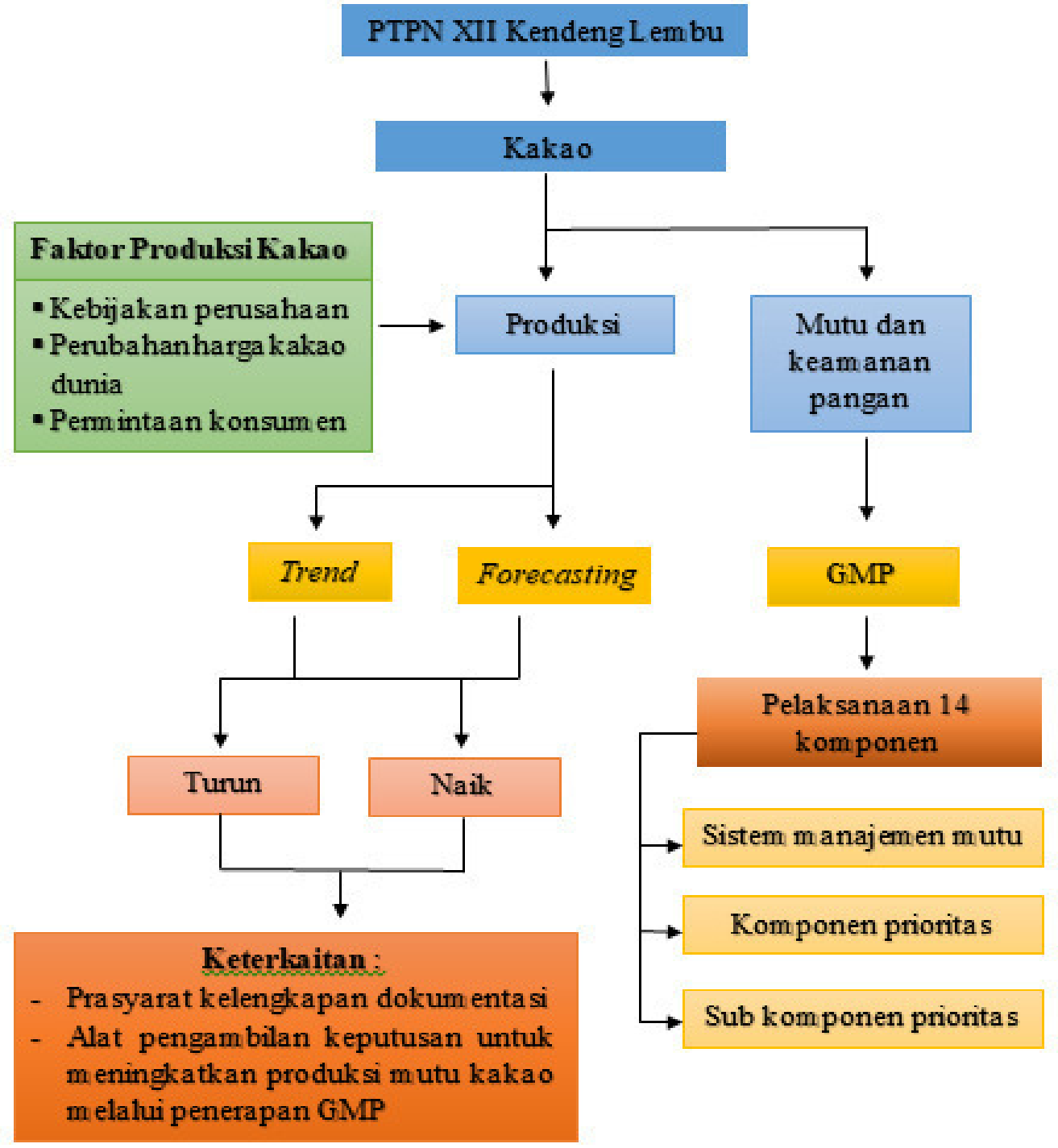

Gambar 2. . Tahapan Penelitian 
Model penelitian yang digunakan dengan menggunakan pendekatan deskriptif dengan analisa kuantitatif. Untuk pengambilan data dilakukan dengan metode survey dan observasi ditunjang dengan data sekunder yang didapat dari instansi terkait.

Metode pengumpulan data dan informasi yang digunakan dalam penelitian ini terdiri dari kuesioner dan wawancara. Kuesioner digunakan untuk mengetahui tingkat penerapan GMP di PTPN XII Kendeng Lembu, sementara teknik wawancara digunakan untuk mengetahui komponen dan sub komponen GMP prioritas di PTPN XII Kendeng Lembu.

Analisis data yang digunakan dalam penelitian ini adalah :

\section{Metode Trend dan Forecasting}

Metode analisa data untuk mengetahui trend produksi kakao yang dihasilkan PTPN XII Kendeng Lembu selama tahun 2006 2016 adalah dengan menggunakan analisa Trend dengan Least Square Method (LSM), sementara untuk teknik peramalan (forecasting) digunakan metode regresi dengan menggunakan SPSS versi 24.

Kriteria pengambilan keputusan menggunakan analisa trend dengan menggunakan metode Least Square Method (LSM) adalah : (1) Jika kurva trend semakin naik, maka menunjukkan perkembangan yang semakin meningkat (positif), dan (2) Jika kurva trend semakin turun, maka menunjukkan perkembangan yang semakin menurun (negatif).

2. Metode Penentuan Level Pelaksanaan GMP

Untuk menentukan tingkat aplikasi GMP di PTPN Kendeng Lembu, peneliti menggunakan kuesioner untuk mengumpulkan data
Data terdiri dari persentase pelaksanaan sub komponen dan komponen GMP. Rumus untuk menghitung tingkat pelaksanaan GMP di setiap komponen adalah :

\section{$\%$ pelaksana}

$$
=\frac{\text { jumlah sub komponen }}{\text { jumlah total sub komponen }}
$$

Setelah diperoleh persentase pelaksanaan GMP, maka pelaksanaan GMP dibagi dalam 3 kategori, yaitu level penerapan GMP rendah, parsial, dan tinggi. Penerapan GMP dikatakan rendah jika persentase kurang dari $50 \%$, penerapan GMP parsial jika persentase pelaksanaan $50 \%$, dan penerapan GMP tinggi jika persentase pelaksanaan lebih dari $50 \%$ (Anonim, 2008).

3. Metode Analysis Hierarchy Process (AHP)

Metode analisis data yang akan digunakan untuk penentuan komponen dan sub komponen prioritas GMP di PTPN XII Kendeng Lembu adalah Analysis Hierarchy Process (AHP). Prinsip dasar dan tahapan metoda AHP adalah : Menyusun hirarki (dekomposisi), pengisian manusia (responden), perhitungan bobot atau nilai vector prioritas dan penilaian konsistensi, dan pengukuran prioritas global (prioritas akhir)

\section{HASIL}

Trend Produksi Kakao yang Dihasilkan PTPN XII Kendeng Lembu selama Tahun 2006 - 2016

Kakao yang dihasilkan PTPN XII Kendeng Lembu terbagi menjadi dua jenis, yaitu kakao bulk dan kakao edel. Tabel 3 memperlihatkan data produksi kakao bulk tahun 2006 - 2016,

Tabel 3. Data Produksi Kakao Bulk Tahun 2006 - 2016

\begin{tabular}{cccr}
\hline TAHUN & LUAS LAHAN $(\mathrm{Ha})$ & $\begin{array}{c}\text { PRODUKSI } \\
(\mathrm{Kg})\end{array}$ & $\begin{array}{c}\text { PRODUKTIVIT } \\
\text { AS }(\mathrm{Kg} / \mathrm{Ha})\end{array}$ \\
\hline $\mathbf{2 0 0 6}$ & 165,60 & 243.279 & 1469,076 \\
$\mathbf{2 0 0 7}$ & 170,60 & 158.773 & 930,674 \\
$\mathbf{2 0 0 8}$ & 185,60 & 145.818 & 785,657 \\
$\mathbf{2 0 0 9}$ & 293,39 & 199.699 & 680,661 \\
$\mathbf{2 0 1 0}$ & 634,06 & 217.505 & 343,035 \\
\hline
\end{tabular}




\begin{tabular}{llll}
\hline $\mathbf{2 0 1 1}$ & 1033,76 & 249.603 & 241,452 \\
$\mathbf{2 0 1 2}$ & 1151,30 & 333.954 & 290,067 \\
$\mathbf{2 0 1 3}$ & 1090,30 & 315.653 & 289,510 \\
$\mathbf{2 0 1 4}$ & 1109,70 & 586.534 & 528,552 \\
$\mathbf{2 0 1 5}$ & 1109,70 & 438.517 & 395,167 \\
$\mathbf{2 0 1 6}$ & 1109,70 & 727.244 & 655,352 \\
\hline
\end{tabular}

Sumber : PTPN XII Kendeng Lembu

Dari data pada tabel 3, produksi kakao bulk di PTPN XII Kendeng Lembu Tahun 2006 - 2016 dirumuskan dalam persamaan trend linier adalah $\mathrm{Y}=-94,910+47,357 \mathrm{X}$. Persamaan ini menunjukkan besarnya nilai koefisien trend 47,357yang berarti peningkatan produksi sebesar 47,357kg setiap - 2016 tahun. Sementara itu diperoleh nilai intersep 94,910yang berarti rata-rata produksi kakao bulk selama 2006 - 2016 yang dihasilkan PTPN XII Kendeng Lembu sebesar 94,910kg. Gambar 3 memperlihatkan dinamika produksi dan produktivitas kakao bulk pada tahun 2006

\section{Produltivitas $(\mathrm{kg} / \mathrm{ha})$}

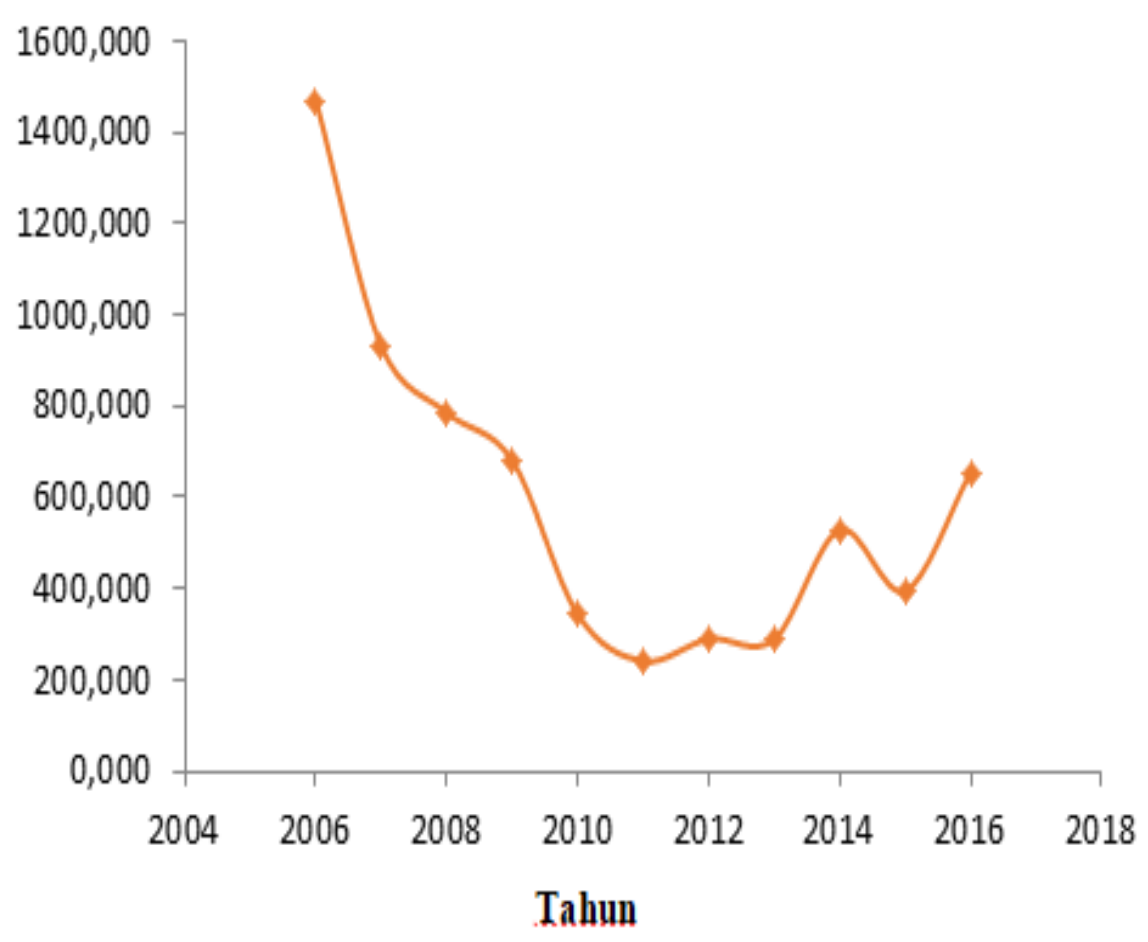

Gambar 3. . Produktivitas Kakao Bulk Tahun 2006 - 2016

Dari gambar 3, tampak diketahui bahwa produktivitas tertinggi pada tahun 2006 yaitu sebesar $1.496,076 \mathrm{~kg} / \mathrm{ha}$ dan mengalami penurunan yang cukup signifikan pada kurun waktu 2009 - 2013. Pada tahun 2007 terdapat penurunan produksi sebesar $34,47 \%$, tahun 2008 mengalami penurunan produksi sebesar 8,16\%, tahun 2009 mengalami peningkatan produksi sebesar $36,95 \%$, 2010 mengalami peningkatan sebesar 8,92\%, 2011 mengalami peningkatan sebesar 14,76\%, 2012 mengalami peningkatan sebesar $33,79 \%$. Pada tahun 2013 mengalami penurunan sebesar 5,48\%. Pada tahun 2014 produksi kakao bulk mengalami peningkatan yang signifikan sebesar $82,82 \%$ dan mengalami penurunan pada tahun 2015 yaitu sebesar 25,24\%. Namun pada tahun 2016 mengalami peningkatan sebesar $65,84 \%$.

Berbeda dengan kakao edel, kakao bulk mengalami peningkatan luas lahan yang 
cukup signifikan. Pada periode 2006 - 2016 terjadi peningkatan luas lahan kakao edel sejumlah $94,41 \%$
Selain kakao bulk, PTPN XII Kendeng Lembu juga memproduksi kakao edel. Tabel 4 memperlihatkan produksi kakao edel PTPN XII Kendeng Lembu Tahun 2006 $-2016$

Tabel 4.. Data Produksi Kakao Edel Tahun 2006 - 2016

\begin{tabular}{cccc}
\hline TAHUN & LUAS LAHAN $(\mathrm{Ha})$ & $\begin{array}{c}\text { PRODUKSI } \\
(\mathrm{Kg})\end{array}$ & $\begin{array}{c}\text { PRODUKTIVITAS } \\
(\mathrm{Kg} / \mathrm{Ha})\end{array}$ \\
\hline $\mathbf{2 0 0 6}$ & 464,90 & 316.180 & 680,103 \\
$\mathbf{2 0 0 7}$ & 464,90 & 154.068 & 331,400 \\
$\mathbf{2 0 0 8}$ & 464,90 & 198.044 & 425,993 \\
$\mathbf{2 0 0 9}$ & 464,90 & 212.315 & 456,690 \\
$\mathbf{2 0 1 0}$ & 500,10 & 96.235 & 192,432 \\
$\mathbf{2 0 1 1}$ & 480,77 & 124.616 & 259,201 \\
$\mathbf{2 0 1 2}$ & 467,12 & 72.206 & 154,577 \\
$\mathbf{2 0 1 3}$ & 231,50 & 39.500 & 170,626 \\
$\mathbf{2 0 1 4}$ & 155,87 & 78.339 & 502,592 \\
$\mathbf{2 0 1 5}$ & 155,87 & 78.080 & 500,930 \\
$\mathbf{2 0 1 6}$ & 155,87 & 66.223 & 424,860 \\
\hline
\end{tabular}

\section{Sumber : PTPN XII Kendeng Lembu}

Dari data pada tabel 4, produksi kakao edel dirumuskan dalam persamaan trend linier adalah $\mathrm{Y}=255,028-20,750 \mathrm{X}$. Persamaan ini menunjukkan besarnya nilai koefisien trend 20,750 yang berarti penurunan produksi sebesar 20,750 kg setiap tahun. Sementara itu diperoleh nilai intersep 255.028 yang berarti rata-rata produksi kakao edel selama 2006 2016 yang dihasilkan PTPN XII Kendeng Lembu sebesar $255,028 \mathrm{~kg}$.

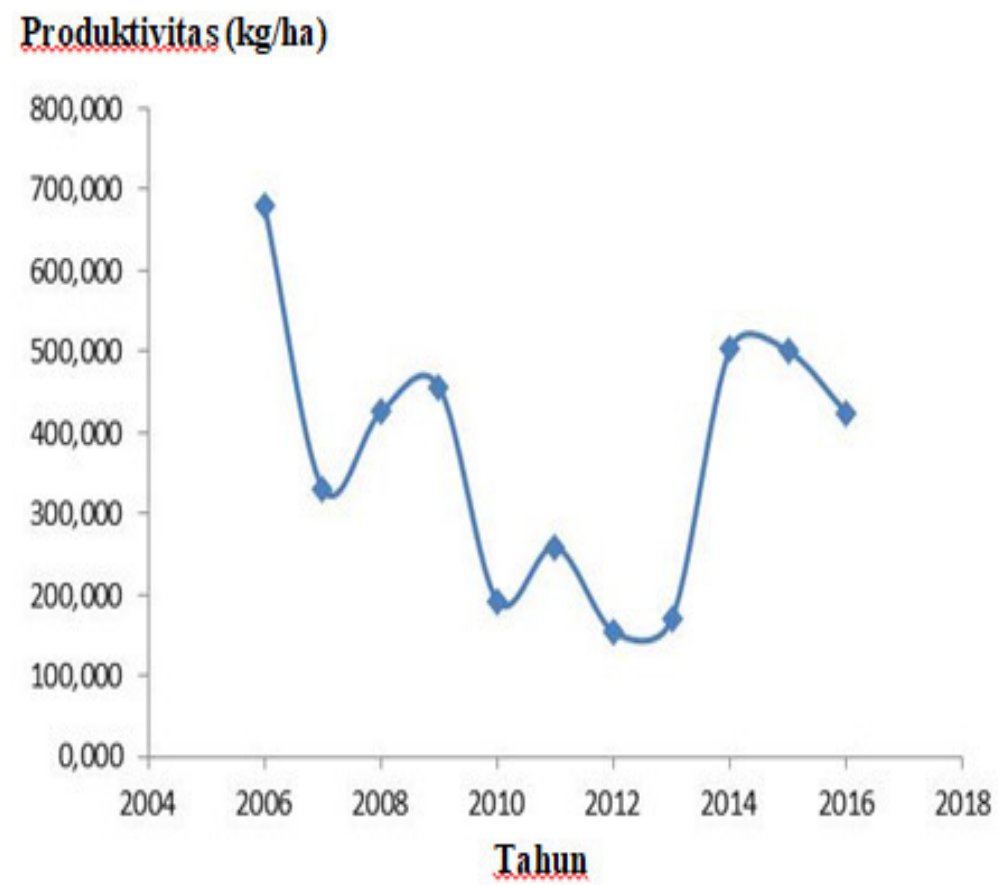

Gambar 4. Produktivitas Kakao Edel Tahun 2006 - 2016

Dari gambar 4, tampak diketahui bahwa produktivitas tertinggi pada tahun
2006 yaitu sebesar 680,103 kg/ha Pada tahun 2007 terdapat penurunan produksi sebesar 
$51,27 \%$, tahun 2008 mengalami peningkatan produksi sebesar 28,54\%, tahun 2009 mengalami peningkatan produksi sebesar $7,21 \%$, 2010 mengalami penurunan sebesar $54,67 \%, \quad 2011$ mengalami peningkatan sebesar 29,49\%, 2012 mengalami penurunan sebesar 42,06\%. Pada tahun 2013 mengalami penurunan sebesar 45,30\%. Pada tahun 2014 produksi kakao edel mengalami peningkatan yang signifikan sebesar $98,33 \%$ dan mengalami penurunan pada tahun 2015 yaitu sebesar $\quad 0,33 \%$. Dan pada tahun 2016 mengalami penurunan sebesar $15,19 \%$.

Penurunan produktivitas kakao edel salah satunya diakibatkan oleh adanya penurunan luas lahan yang cukup signifikan. Pada periode tahun 2006 - 2016 terjadi penurunan luas lahan 30,903\%. Dan pada periode 2014 - 2016, luas lahan yang digunakan untuk menanam kakao edel tidak mengalami penambahan $(155,87 \mathrm{ha})$.

\section{Penerapan GMP Di PTPN XII Kendeng Lembu}

Terdapat 14 komponen dalam penerapan GMP yang dilakukan, yaitu lokasi, bangunan, fasilitas sanitasi, alat produksi, bahan, proses pengolahan, produk akhir, laboratorium, karyawan, kemasan, label, penyimpanan, pemeliharaan, dan transportasi

Dari serangkaian perhitungan, diketahui bahwa tingkat pelaksanaan GMP di PTPN XII Kendeng Lembu Banyuwangi secara keseluruhan adalah sebesar 65,95\% yang artinya adalah tingkat penerapan komponen dan sub komponen GMP di PTPN XII Kendeng Lembu tergolong agak tinggi. Tingkat pelaksanaan GMP yang tergolong tinggi adalah lokasi, bangunan, alat produksi, bahan, proses pengolahan, dan pemeliharaan.

Hal ini tampak pada tabel 5 yang berisi tentang tingkat penerapan GMP di PTPN XII Kendeng Lembu Banyuwangi

Tabel 5. Tingkat Penerapan GMP di PTPN XII Kendeng Lembu

\begin{tabular}{llcc}
\hline $\begin{array}{l}\text { Persyaratan dan Penerapan } \\
\text { GMP }\end{array}$ & \% Pelaksanaan & Kriteria \\
\hline $\mathbf{1}$ & Lokasi & 100,00 & Tinggi \\
$\mathbf{2}$ & Bangunan & 82,89 & Tinggi \\
$\mathbf{3}$ & Fasilitas Sanitasi & 60,00 & Agak Tinggi \\
$\mathbf{4}$ & Alat Produksi & 82,50 & Tinggi \\
$\mathbf{5}$ & Bahan & 100,00 & Tinggi \\
$\mathbf{6}$ & Proses Pengolahan & 78,33 & Tinggi \\
$\mathbf{7}$ & Produk Akhir & 66,67 & Agak Tinggi \\
$\mathbf{8}$ & Laboratorium & 0,00 & Rendah \\
$\mathbf{9}$ & Karyawan & 38,75 & Rendah \\
$\mathbf{1 0}$ & Kemasan & 66,67 & Agak Tinggi \\
$\mathbf{1 1}$ & Label & 56,50 & Parsial \\
$\mathbf{1 2}$ & Penyimpanan & 49,29 & Parsial \\
$\mathbf{1 3}$ & Pemeliharaan & 75,00 & Tinggi \\
$\mathbf{1 4}$ & Transportasi & 66,75 & Agak Tinggi \\
RERATA & $\mathbf{6 5 , 9 5}$ & \\
\hline
\end{tabular}

Sementara elemen-elemen GMP untuk PTPN XII Kendeng Lembu tercantum pada mengetahui prioritas pelaksanaan GMP di tabel 6 .

Tabel 6. Elemen Penerapan GMP di PTPN XII Kendeng Lembu

\begin{tabular}{llc}
\hline \multicolumn{2}{c}{ Persyaratan dan Penerapan GMP } & \% Pelaksanaan \\
\hline $\mathbf{1}$ & Lokasi & $\mathbf{1 0 0 , 0 0}$ \\
& a. Lokasi pabrik harus bebas cemaran & 100,00 \\
& b. Lokasi pabrik harus pada tempat yang baik & 100,00 \\
c. $\quad$ Sesuai dengan aturan yang berlaku dalam UU & 100,00 \\
\hline
\end{tabular}


Lingkungan Hidup
d. Aman
100,00

2 Bangunan

$\mathbf{8 2 , 8 9}$

a. Ketentuan umum $\quad 75,00$

b. Tata Ruang 100,00

c. Lantai $\quad 86,00$

d. Dinding 100,00

e. Atap dan langit-langit $\quad 50,00$

f. Pintu $\quad 75,00$

g. Jendela 100,00

h. Penerangan 100,00

i. Ventilasi dan pengatur suhu ruangan pokok 60,00 dan penegkap

3 Fasilitas Sanitasi $\quad \mathbf{6 0 , 0 0}$

a. Ketentuan umum 100,00

b. Sarana penyediaan air $\quad 100,00$

c. Sarana pembuangan $\quad 100,00$

d. Sarana toilet 0

e. Sarana cuci tangan 0

f. Sarana lainnya $\quad 60,00$

4 Alat Produksi $\quad \mathbf{8 2 , 5 0}$

a. Persyaratan alat produksi sebelum digunakan $\quad 80,00$

b. Alat dan perlengkapan harus memenuhi 85,00 persyaratan teknis dan higienis

c. Persyaratan alat dan perlengkapan $\quad 85,00$

d. Pemisahan dan penandaan alat produksi $\quad 80,00$

5 Bahan

$\mathbf{1 0 0 , 0 0}$

a. Syarat bahan baku yang digunakan untuk 100,00 memproduksi makanan

b. Pengendalian pengadaan bahan $\quad 100,00$

c. Penempatan bahan baku yang akan diproses 100,00 harus dipisahkan dengan bahan lain yang berbahaya

d. Penyimpanan bahan baku

6 Proses Pengolahan

78,33

a. Formula dasar $\quad 100,00$

b. Pengendalian proses

c. Kode produksi (batch number)

100,00

d. Produksi bersih

7 Produk Akhir

a. Produk akhir tidak merugikan dan 100,00 membahayakan kesehatan

b. Inspeksi rutin untuk menjamin mutu dan 100,00 keamanan produk (organoleptic)

c. Uji fisika, kimia, mikrobiologi dilakukan 0 secara periodik dan sewaktu-waktu apabila diperlukan

8 Laboratorium

a. Kepemilikan laboratorium oleh perusahaan

b. Persyaratan pemeriksaan di laboratorium

9 Karyawan

80,00

33,33

$\mathbf{6 6 , 6 7}$

0

0

0 


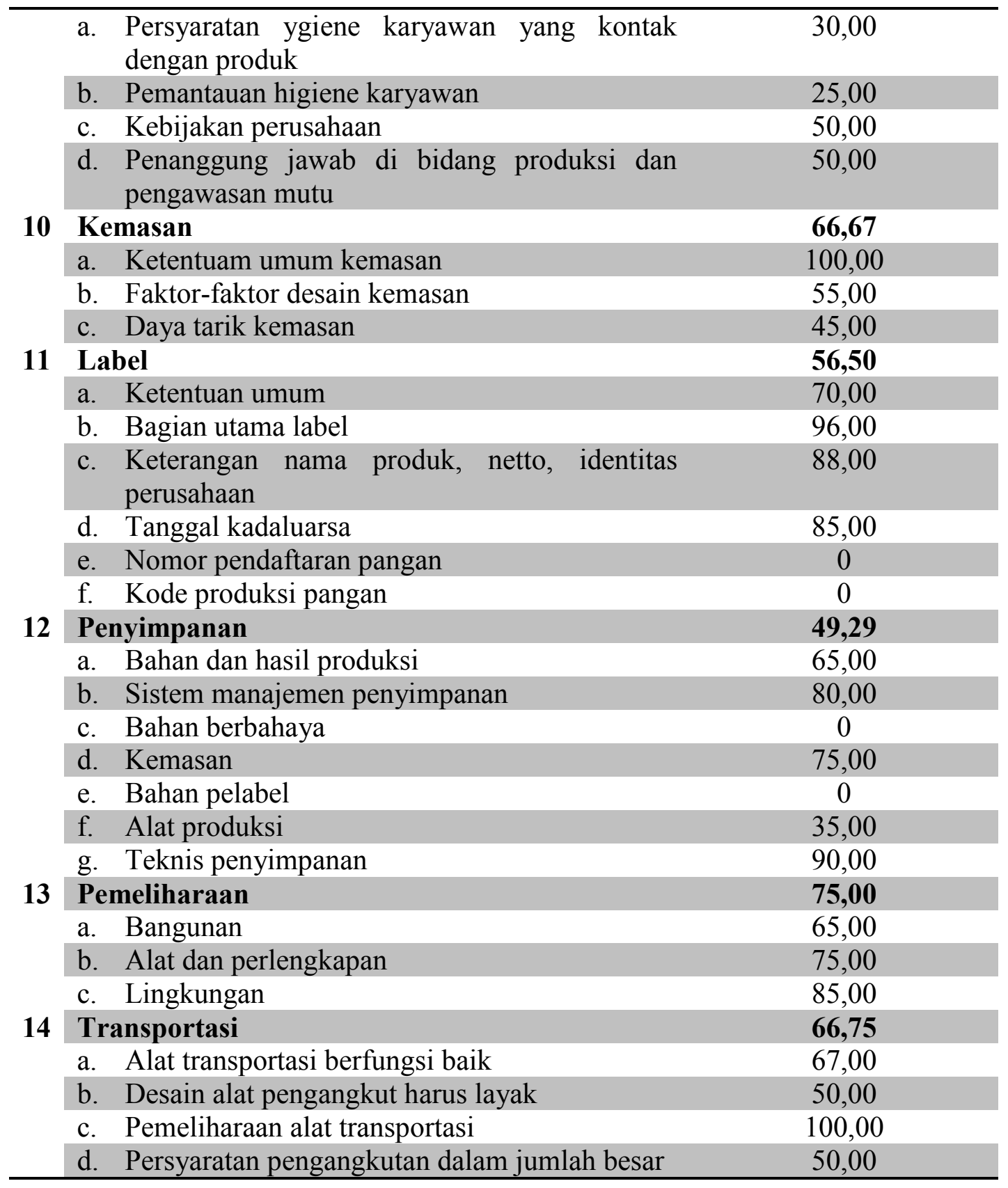

\section{GMP Prioritas di PTPN XII Kendeng}

\section{Lembu}

GMP prioritas di PTPN XII Kendeng Lembu dilakukan dengan menggunakan AHP.

a. Lokasi

Sub komponen yang menjadi perhatian adalah : (1) Pada tempat yang baik (2) aman, (3) sesuai dengan aturan yang berlaku dalam UU Lingkungan Hidup, dan (4) bebas cemaran. Semua aspek sudah dilaksanakan dengan baik, sehingga level AHP dalam kondisi "mempertahankan". b. Bangunan

Sub komponen yang diukur adalah : (1) penerangan, (2) dinding, (3) ventilasi dan pengatur suhu ruangan pokok dan ruangan pelengkap lantai, (4) atap dan langitlangit, (5) jendela, (6) ketentuan umum, (7) lantai, (8) pintu, (9) tata ruang. Pelaksanaan sub komponen atap dan langit-langit, dan ventilasi dan pengatur suhu ruangan pokok dan ruangan pelengkap lantai masih rendah sehingga membutuhkan perhatian lebih untuk dikelola lebih baik lagi

c. Fasilitas Sanitasi 
Sub komponen yang diukur adalah : (1) ketentuan umum, (2) sarana penyediaan air, (3) sarana pembuangan, (4) sarana toilet, (5) sarana cuci tangan, (6) sarana lainnya. Yang perlu diperbaiki dan ditingkatkan adalah sub komponen sarana toilet, sarana cuci tangan, dan sarana lainnya

d. Alat Produksi

Sub komponen alat produksi adalah : (1) alat dan perlengkapan yang dipakai harus sesuai dengan persyaratan teknis dan higienis, (2) persyaratan alat produksi, (3) Persyaratan alat produksi sebelum digunakan, dan (4) Pemisahan dan penandaan alat produksi. Kondisi sub komponen alat produksi sudah cukup baik hanya kurang optimal sehingga dalam kondisi "meningkatkan"

e. Bahan

Sub komponen bahan : (1) Syarat bahan baku yang digunakan untuk memproduksi makanan, (2) Pengendalian pengadaan bahan (procurement control),

Penempatan bahan baku yang akan diproses harus dipisahkan dengan bahan lain yang berbahaya, (4) Penyimpanan bahan baku berada dalam kondisi optimal sehingga sub komponen ini harus "mempertahankan"

f. Proses Pengolahan

Sub komponen proses pengolahan : (1) formula dasar, (2) pengendalian proses, (3) kode produksi (batch number), dan (4) produksi bersih. Untuk kondisi formula dasar dan pengendalian proses tidak ada masalah sehingga dalam kondisi "mempertahankan", sementara untuk kode produksi dalam kondisi "meningkatkan" dan produksi bersih dalam kondisi "memperbaiki"

g. Produk Akhir

Sub komponen produk akhir dari urutan tertinggi ke terendah adalah : (1) Produk akhir tidak merugikan dan membahayakan kesehatan, (2) Inspeksi rutin untuk menjamin mutu dan keamanan produk (organoleptic), dan (3) Uji fisika, kimia, mikrobiologi dilakukan secara periodik dan sewaktu-waktu apabila diperlukan. Untuk poin (1) dan (2) dalam kondisi "mempertahankan", sementara tidak disediakannya uji fisika, kimia, mikrobiologi membuat sub komponen ini dalam kondisi "memperbaiki

h. Laboratorium

Untuk komponen laboratorium dengan sub komponen : (1) Kepemilikan laboratorium oleh perusahaan, dan (2) Persyaratan pemeriksaan di laboratorium dalam kondisi "meningkatkan dan memperbaiki" dikarenakan di PTPN XII Kendeng Lembu tidak terdapat laboratorium.

i. Karyawan

Komponen karyawan dengan sub komponen : (1) Penanggung jawab di bidang produksi dan pengawasan mutu, (2) Kebijakan perusahaan, (3)Persyaratan higiene karyawan yang kontak dengan produk, dan (4) pemantauan hygiene karyawan berada dalam kondisi "meningkatkan dan memperbaiki"

\section{j. Kemasan}

Sub komponen sesuai urutan tertinggi ke terendah : (1) Ketentuam umum kemasan, (2) Faktor-faktor desain kemasan, dan (3) Daya tarik kemasan. Untuk poin (1) sudah dalam kondisi baik dan optimal, sehingga posisinya adalah "mempertahankan", sementara poin (2) dan (3) dalam kondisi kurang optimal, sehingga harus "meningkatkan dan memperbaiki"

k. Label

Untuk sub komponen label : (1) Bagian utama label, (2) Keterangan nama produk, netto, identitas perusahaan, dan (3) Tanggal kadaluarsa, dalam kondisi yang optimal sehingga posisinya adalah "mempertahankan. Sementara sub komponen : (4) Ketentuan umum, (5) Nomor pendaftaran pangan, dan (6) Kode produksi pangan dalam kondisi "meningkatkan dan memperbaiki" untuk lebih optimal lagi

1. Penyimpanan

Dari urutan tertinggi ke terendah : (1) Teknis penyimpanan, (2) Sistem manajemen penyimpanan, dan (3) Kemasan, cukup baik dalam pengelolaannya. Sehingga dalam posisi 
"mempertahankan". Sementara untuk sub komponen : (4) Bahan dan hasil produksi, (5) Alat produksi, (6) Bahan pelabel, dan (7) Bahan berbahaya harus lebih diperbaiki lagi.

m. Pemeliharaan

Pemeliharaan memiliki 3 sub komponen.

Dua diantaranya dalam kondisi optimal sehingga posisinya adalah "mempertahankan", yaitu : (1) Lingkungan, dan (2) Alat dan perlengkapan. Sementara untuk sub komponen (3) Bangunan dalam posisi "meningkatkan dan memperbaiki

n. Transportasi

Sub komponen transportasi yang dalam kondisi "mempertahankan adalah : (1) pemeliharaan alat transportasi dan (2) persyaratan pengangkutan dalam jumlah besar. Sementara untuk sub komponen (3) alat transportasi berfungsi baik dan (4) desain alat pengangkut harus layak, perlu "ditingkatkan dan diperbaiki

\section{KESIMPULAN}

1. Peramalan trend produksi kakao bulk di PTPN XII Kendeng Lembu dirumuskan $\mathrm{Y}=-94,910+47,357 \mathrm{X}$, yang artinya terdaopat peningkatan produksi sebesar $47,357 \mathrm{~kg}$ setiap tahun. Sementara itu rata-rata produksi kakao bulk selama 2006 - 2016 yang dihasilkan sebesar $94,910 \mathrm{~kg}$

2. Peramalan trend produksi kakao edel di PTPN XII Kendeng Lembu Tahun 2006 - 2016 dirumuskan dalam persamaan trend linier $\mathrm{Y}=255,028-20,750 \mathrm{X}$. Persamaan ini menunjukkan terdapat penurunan produksi sebesar $20,750 \mathrm{~kg}$ setiap tahun dan rata-rata produksi kakao edel selama 2006 - 2016 yang dihasilkan PTPN XII Kendeng Lembu sebesar 255, $028 \mathrm{~kg}$.

3. Tingkat pelaksanaan GMP di PTPN XII Kendeng Lembu Banyuwangi secara keseluruhan adalah sebesar $65,95 \%$ yang artinya adalah tingkat penerapan komponen dan sub komponen GMP di
PTPN XII Kendeng Lembu tergolong agak tinggi.

4. Untuk prioritas pelaksanaan GMP di PTPN XII Kendeng Lembu Banyuwangi , maka yang perlu mendapat perhatian adalah : Sarana toilet, Sarana cuci tangan, Uji fisika, kimia, mikrobiologi dilakukan secara periodik dan sewaktu-waktu apabila diperlukan, Nomor pendaftaran pangan, Kode produksi pangan, Bahan berbahaya, Bahan pelabel, Pemantauan higiene karyawan, Persyaratan higiene karyawan yang kontak dengan produk, Produksi bersih, Alat produksi , Daya tarik kemasan , Atap dan langit-langit , Kebijakan perusahaan , Penanggung jawab di bidang produksi dan pengawasan mutu, Desain alat pengangkut harus layak, Faktor-faktor desain kemasan, Ventilasi dan pengatur suhu ruangan pokok dan pelengkap , Bahan dan hasil produksi , Bangunan , Alat transportasi berfungsi baik, dan Ketentuan umum transportasi

\section{UCAPAN TERIMAKASIH}

Penulis mengucapkan terimakasih kepada Direktorat Riset dan Pengabdian Kepada Masyarakat, Kemeristekdikti, Republik Indonesia yang telah memberikan dukungan dana guna pelaksanaan kegiatan penelitian ini.

\section{DAFTAR PUSTAKA}

Anonim, 2008, Good Manufacturing Practices and Implementation, GMP Publishing http://www.gmppublishing.com/diakses 5 Maret 2017

Direktorat Jenderal Pengolahan dan Pemasaran Hasil Pertanian, Departemen Pertanian, 2003, Kebijakan dan Program Pemasaran dan Pengembangan Industri Kopi di Indonesia, Warta Pusat Penelitian Kopi dan Kakao, 19(1) : $9-21$ 
Direktorat Jenderal Perkebunan, 2016.

Outlook Kakao, Komoditas

Pertanian, Subsektor Perkebunan,

Pusat Data dan Sistem Informasi

Pertanian, Sekretaris Jenderal-

Kementerian Pertanian

Gasperz, Vincent, 2008, Total Quality

Management, , PT. Gramedia

Pustaka Umum, Jakarta

Sauer, T.M., 2007, How Your GMP Program

Affects The Bottom Line, Food

Safety Magazine, 11.4.

Supriyati, dkk, 2006, Analisis Peningkatan Nilai Tambah Melalui

Agroindustri, Laporan Akhir Penelitian, Pusat Analisis Sosial Ekonomi dan Kebijakan Pertanian, Badan Penelitian dan Pengembangan Pertanian, Divisi Pertanian, Bogor

Supriyati dkk, 2006. Peranan, Peluang, dan Kendala Pengembangan Agroindustri di Indonesia, Forum Penelitian Agro Ekonomi 24 (2): 92-106, Pusat Analisis Sosial Ekonomi dan Kebijakan Pertanian Bogor

Thaheer, 2005, Sistem Manajemen HACCP (Hazard Analysis Critical Control Point), Bina Aksara, Jakarta

Wuryaningsih, E., 2007. Kebijakan Pemerintah dalam Pengamanan Pangan Asal Hewan. Prosifing Lokakarya Nasional Keamanan Pangan Produk Peternakan, Bogor, 14 September 2007, Pusat Penelitian dan Pengembangan Peternakan, Bogor 